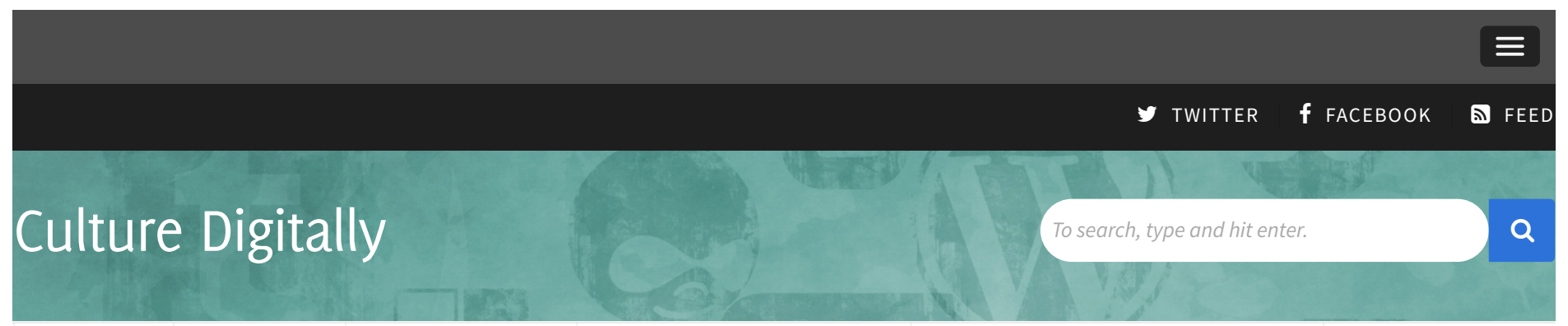
HOME
ABOUT
DIALOGUES
DIGITAL KEYWORDS
FESTIVAL OF MEMEOLOGY

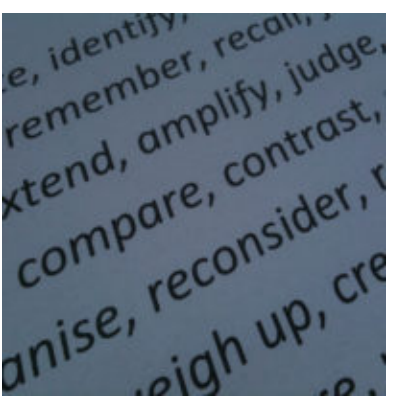

\section{The Trials of Media Research}

JEFF POOLEY · JULY 31, 2018

Media research is a vexing enterprise. Trapped in the borderlands between social science and the humanities, the study of media and communication bears the liabilities of both. We have to contend with all the challenges that sociologists and literary scholars face: the subjective baggage of the analyst, her struggle to interpret unstable meanings, the strange fact that her descriptions double back on the reality she purports to merely describe. Those are our challenges too, but we face them with special ferocity. The stuff that we study-internet memes, for example, or self-learning algorithms-are characterized by ceaseless churn. Even the categories we use, like "audience" or "content" or "producer," get washed away by the pace of change. There is nothing fixed or frozen to linger on; everything we study is on the move, looping, dynamic, and messy. The word itself, "media," gets at this fundamental instability: a medium is something in between, the airy space in the interstices of solider things.

So we can't pretend to be a "science," not in the confident sense at least. We are better off, as media scholars, submitting to our inadequacy. This means humility as a disposition of principle. Everything we say is tentative and revisable-good enough, at best, for the moment. But not for the next.
With support from:

The National Science Foundation, Temple University, and Cornell University

\section{TRAFFIC \\ THROTTLING? \\ SITE BLOCKING? \\ NEW FEES? \\ NO THANKS.}

\section{SAVE \\ NET NEUTRALITY.}

\#CULTD

Tweets about "\#cultd"

FOUNDERS

Tarleton Gillespie

Hector Postigo

Josh Braun

Sam Srauy 


\section{The Problem of Researcher Subjectivity}

Scholars of all stripes have values, beliefs, and prejudices, just like all human beings. Try as they might, researchers can never bracket-not all the way-their situated, partial humanity that they bring to bear on their objects of study. A measure of this subjectivity isn't even conscious, embedded as it is in language and taken-for-granted assumptions. Even the choice of what to study is irredeemably value-laden: why this, and not that? All of which is to say that there is no window on the world, no "god'seye" view, no "objectivity" in academic inquiry. This is as true of physics as it is of economics, but the consequences for social research are far more hobbling. A social researcher's mix of beliefs and assumptions, what we might call his worldview, is of the same, human kind as the people and communities that he studies. He brings subjectivity to bear on other subjectivities. For the historian or anthropologist, this state of affairs poses a special challenge, that of overcoming distance: a gap in time, or in cultural difference.

For the media scholar the problem is reversed: Our subjects of study very often share our world. We use smartphone apps, for example, to record our subjects' obsession with smartphone apps. Or we may study Game of Thrones fan fiction through the prism of our own consumption. Our problem, in other words, is the blindness of proximity. The task we face is not, like the historian or anthropologist, to make the strange familiar, but the opposite tack: to make the familiar strange.

\section{The Problem of Social Change}

Natural scientists tend to study more-or-less stable things-like rocks for a geologist-with an eye to finding general patterns or even "laws". Gravity behaves the same way everywhere in the universe. A pathogen that caused pneumonia a hundred years ago will, barring medical intervention, do the same today.

Social researchers, in contrast, have nothing stable to cling to. The shared practices of any given human community may or may not resemble another. The only guarantee is that both will change over time, and in reaction to mutual contact. Scholars of the social, as a result, study a moving target. A 1950s book on European marriage, for example, may have reflected the norms
AUTHORS

Adam Fish

Adrienne Shaw

Alice Marwick

Alison Harvey

Andrés Monroy-Hernández

Anne Helmond

Annette markham

Alison Novack

Aphra Kerr

Arturo Arriagada

Aynne Kokas

Ben Peters

Elizabeth Wissinger

Brooke Erin Duffy

Burcu S. Bakioglu

C.W. Anderson

Carla Ilten

Carrie Rentschler

Casey O'Donnell

Christina Dunbar-Hester

Christopher Boulton

Chuck Tryon

Dan Greene

Daniel Kreiss

Daren Brabham

Dawn Nafus

Daniel Guagnin

Eugenia Mitchelstein

Fenwick McKelvey

Finn Brunton

Fred Turner

Gabriella Coleman

Gina Neff

Greg Lastowka

Graham Meikle

Guobin Yang

Hope Forsyth

Hugh Gusterson

Ilana Gershon

Jan Fernback

James Bennett

Jean Burgess

John Carter McKnight

Jeff Drouin

Jennifer Lena

Jessa Lingel 
and practices prevailing at the time; but Europeans today are far less likely to marry at all. It's not that the 1950s book was inaccurate; it's just outdated.

Media scholars face this problem of change at the pace of Silicon Valley. The interaction of markets, people and technologies means that change, for us, is more like a rolling boil. A networked babel of human meanings feed responsive algorithms that, in turn, circulate new meanings, all of it mediated by relentlessly updated software and hardware. If the plodding pace of academic publishing hardly seems up to the task, that's because we can never pause long enough to take stock-or if we do, it's already too late.

\section{The Problem of Interactive Kinds}

Unlike rocks and quasars, human beings can (and do) respond to the way they are described. A quasar, after all, does not change its self-definition after an astrophysicist labels it. Rocks and quasars are indifferent to the words we use to understand them. But humans live in a world of meanings, and these meanings include the ones that social researchers circulate. Take the label "homosexual," which gained academic currency in the late 19th century to describe same-sex behavior. The term was adopted, in the West, as a clinical diagnosis-as a medicalized, treatable pathology. Many LGBT persons adopted the label, and their self-concepts changed as a result. Over time, and with special force in the first decades of the gay rights movement, the term itself was rejected for its pathologizing residues. Here is an example of what the philosopher lan Hacking calls the "looping effects of human kinds": an academic/clinical label was adopted and transformed by the labeled, requiring scholars and clinicians to adapt.

Social researchers, because they study self-interpreting animals (i.e., humans), must make sense of a social world that reacts to their documenting efforts. Social research is an interactive endeavor, an unstable loop of researchers and the researched. There are, as you might guess, ethical implications. The act of studying, prodding, labeling, and measuring is always part of the story, since the observed are thinking, reacting agents themselves. In some sense scholars enact the world they claim to merely depict.
Jesse Houf

Jessica Beyer

Joan Donovan

Joe Turow

John Banks

John Durham Peters

John Sullivan

Jonathan Sterne

Joshua McVeigh-Schultz

Jeff Pooley

Julia Sonnevend

Karin Wahl-Jorgensen

Karine Nahon

Kate Zyskowski

Katherine D. Harris

Katy Pearce

Kevin Driscoll

Kate Miltner

Laura Forlano

Lee Humphreys

Lee Vinsel

Limor Shifman

Lisa Nakamura

Lonny J Avi Brooks

Lisa Silvestri

Lucas Graves

Mack Hagood

Mari Castaneda

Mark Chen

Mark Deuze

Mary Gray

Matthew Crain

Matt Ratto

Mél Hogan

Mel Stanfill

Mélanie Millette

Mike Ananny

Neal Thomas

Nicholas John

Nick Couldry

Niels van Doorn

Natalie Stroud

Niki Strange

Paul Hillier

Pablo Boczkowski

Patrick Vonderau

Phil Howard

Rasmus Nielsen

Ray Fouche

Rena Bivens

Ryan Milner

Robert Gehl

Rodrigo Zamith 
For media scholars the challenge-in a now-familiar pattern-is more acute. The material that we write about, and thereby characterize, celebrate or condemn, is earth-bound and ordinary, the stuff of everyday life. We can't even pretend to be detached observers, since our language and research tools are bound up in the popular media culture that we aim to understand.

\section{The Verstehen Problem}

Social researchers, as you know, can't merely describe behavior and institutions like a biologist would an ant colony. The observable patterns aren't enough for human scientists, since there's a whole world of meaning and interpretation that stands behind the way people interact. Following the great German sociologist Max Weber, we can use verstehen to refer to the scholarly effort to reconstruct the meanings people make and circulate. A famous American anthropologist, Clifford Geertz, explained the point:

Believing, with Max Weber, that man is an animal suspended in webs of significance he himself has spun, I take culture to be those webs, and the analysis of it to be therefore not an experimental science in search of law but an interpretative one in search of meaning.

There is an obvious difficulty in all this: how does one gain access to these meanings, and aren't the scholar's summaries, anyway, mere interpretations (of interpretations)? Even if anthropologists or others manage to reconstruct these "webs of significance" with more or less fidelity, aren't these meanings so particular and fleeting as to be worthless?

If pinning down patterned meanings is a problem for all social researchers, the effort is especially taxing for media scholars. What is the meaning of a GIF that spreads from an Irish teenager to a Chinese septuagenarian in five minutes? Since we investigate the in-between-since the detritus of a viral media culture is unstable by definition-the effort to locate stability looks like a fool's errand. We study the interstitial, the evanescant, the networked: meaning-in-motion.
Rosemary Avance

Samuel Woolley

Sara Kingsley

Sarah Banet-Weiser

Saugata Bhaduri

Scott Brennen

Seth Lewis

Shawn Walker

Shira Chess

Shreeharsh Kelkar

Sean Lawson

Stephanie Schulte

Steven Schrag

Tamara Shepherd

Ted Striphas

Tim Highfield

Thomas Streeter

Tim Jordan

Tom Boellstorff

Tony Liao

Torin Monahan

Valerie Belair-Gagnon

Whitney Phillips

Zachary McDowell

Zizi Papacharissi

ARCHIVES

Archives Select Month

LINKS FOR CONTRIBUTORS

$\log \ln$ 


\section{The Problem of the Unobserved}

The social world that human scientists study is made up of more than meanings. There is, too, the harder stuff of structure, much of which operates outside our everyday experience. Consider a t-shirt featuring a band, that you bought at a concert. The shirt has meanings that a scholar might tease out in terms, say, of your performance of identity, or your taste profile. But what about the global supply chain that brought the shirt to the concert in the first place? The South Asian factory, the Danish shipping company, the New York-based trademark clearance operation, the record company's bulk order-none of that registered with you, yet your purchase set it all in motion. Wide swaths of social life have this "behind people's backs" character. The researcher's task is to describe these hidden structures, to render them legible to policy-makers and, in theory, to the democratic public.

For the 20th century media scholar, this task resembled the sociologist's or the economist's. A media industry researcher might study the ownership structure of major media conglomerates, and write about the implications. That kind of work wasn't too different from a political scientist studying global diplomacy, or an economist studying the labor market: the media scholar, like the others, is representing a complex structure in charts and words. But what about our 21st-century media culture, deeply entangled as it is with algorithms-the complex, self-adjusting software code that governs so much of our online life? Because of their sheer complexity, and because they can "learn" from their human inputs, algorithms are at least partly inscrutable. Even the engineers who maintain Google's search algorithms claim not to comprehend the ranking system they initially authored. The system is so complex, and constantly evolving "on its own" that they too struggle to guess what's in the black box. So it's not just that Google and Facebook guard their algorithms like state secrets; it may be impossible, even in principle, for media scholars to explain these unseen motors of popular culture. 


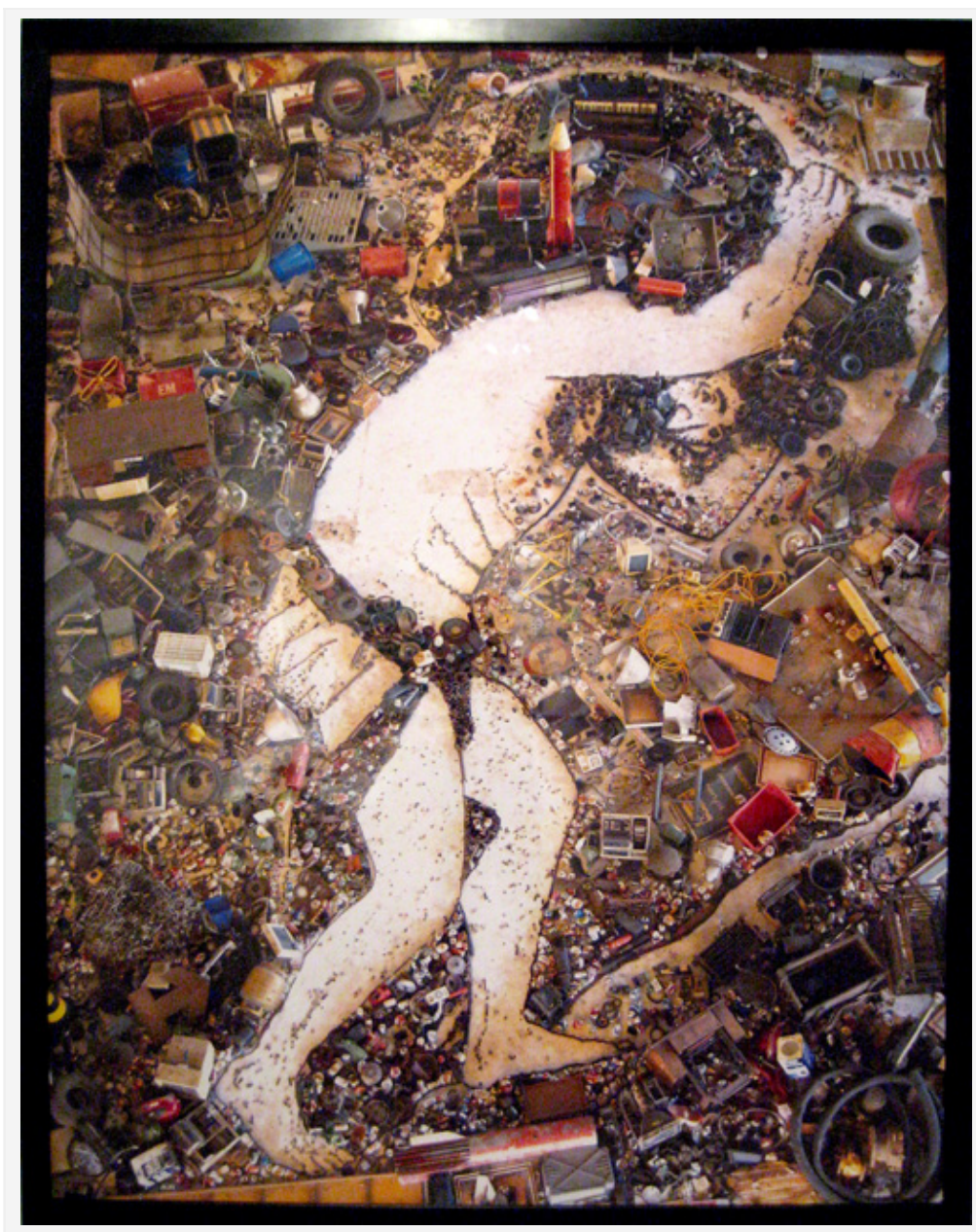

Sisyphus, After Tiziano by Vik Muniz

\section{A Humble Enterprise}

After this catalog of limitations, why go on with media research at all? It's a fair question. In the Greek myth of Sysiphus, the gods punished the wayward king by fating him to push a boulder up a hill, only to watch it roll back-over and over, through eternity. There's something Sysiphean about media research.

But the endeavor is still worth something. There are, first, the intellectual pleasures of question-asking themselves. Maybe because it's changing so fast, the media landscape is endlessly fascinating. Only the truly uncurious would find its study boring.

It's also true that the stakes are simply high. Nearly every human on earth lives in and around media, to an extent that makes human cultures a hundred years in the past unrecognizable to 
us. The process-noun that media scholars use to capture this extraordinary bundle of changes is "mediatization." The centrality of mediatized worlds in every facet of our social lifepolitics, medicine, war, immigration, the workplace-is both inescapable and recent. The topic is too big to walk away from.

So we need to keep pushing the boulder up the hill, but with all the humility we can muster. Our findings, we should announce unblushingly, are always and already inadequate. We might even make a habit of repeating why this is the case, just to keep academic hubris at bay. By foregrounding these limits, and by sustaining a culture of peer criticism, we can go about our humble work.

Note: This brief essay was originally written for students in my advanced undergraduate methods course. I am posting here with the hope that it might prove useful in similar or other contexts.

\begin{tabular}{|c|c|c|c|c|c|}
\hline 66 & & 96 & 0 & 0 & 0 \\
\hline$y$ Tweet & Like & ff Share & (D Pin & in Share & $\nabla_{\text {Email }}$ \\
\hline
\end{tabular}

POSTED IN: UNCATEGORIZED

AUTHOR

Jeff Pooley

Associate Professor of Media \& Communication at Muhlenberg College

(jeffpooley.com) 